\begin{tabular}{c} 
Volume and Issues Obtainable at Center for Sustainability Research and Consultancy \\
Journal of Business and Social Review in Emerging Economies \\
ISSN: 2519-089X (E): 2519-0326 \\
Volume 6: No. 1, March 2020 \\
CSRᄃ \\
Journal homepage: www.publishing.globalcsrc.org/jbsee \\
\hline
\end{tabular}

\title{
Presentation of Pakistan's Image: Thematic analysis of Editorials of The Washington Post
}

\author{
${ }^{1}$ Samia Manzoor, ${ }^{2}$ Aasima Safdar, ${ }^{3}$ Aqsa Iram Shahzadi
}

${ }^{1}$ Assistant Professor of Communication Studies, Bahauddin Zakariya University, Multan, Pakistan:samia.manzoor@bzu.edu.pk

2 Assistant Professor of Communication Studies, Bahauddin Zakariya University, Multan, Pakistan

${ }^{3}$ Assistant Professor of Communication Studies, Bahauddin Zakariya University, Multan, Pakistan

\begin{tabular}{l} 
ARTICLE DETAILS \\
\hline History \\
Revised format: February 2020 \\
Available Online: March 2020 \\
\hline Keywords \\
The Washington Post, thematic \\
analysis, image of Pakistan, \\
editorial presentation
\end{tabular}

JEL Classification:

D78

\begin{abstract}
The present research aims to study the image of Pakistan through identifying the themes which are used by the editorials of The Washington Post. The population of the study comprised of editorials of The Washington Post that have the word Pakistan in title or in opening paragraph. A total of 116 editorials were analyzed with the help of NVIVO 10 that identified eight different themes. The thorough analysis of the data revealed that the newspapers mostly wrote about Pakistan through the following themes: Pakistan backing Taliban, negative image of President Musharraf, democracy in Pakistan, nuclear technology and Pakistan government, Pakistan's operation against terrorism, Indian terrorist attacks, US military operation and Osama bin Laden, and social issues in Pakistan. It was also observed that Pakistan was presented in a very negative way. General Pervez Musharraf was very harshly criticized. Overall Pakistan was presented as a frail, threatening and monstrous country. Pakistan policy makers must develop counter strategies to combat this negative image building.
\end{abstract}

(C) 2020 The authors, under a Creative Commons AttributionNonCommercial 4.0

Corresponding author's email address: samia.manzoor@bzu.edu.pk

Recommended citation: Manzoor,S., Safdar,A., \& Shahzadi,A.I. (2020). Presentation of Pakistan's Image: Thematic analysis of Editorials of The Washington Post. Journal of Business and Social Review in Emerging Economies, 6(1), 229-238

DOI: $10.26710 /$ jbsee.v6i1.1042

\section{Introduction}

Mass media is ranked as one of the most influential ways to communicate with the masses (Uudelepp, 2008). Effective message dissemination is impossible without the clever use of media. Media plays a key role in provision of information to the masses. The role of media becomes even more significant in a democratic society where it becomes a bridge between the society and policy makers (Boaz, 2005). Media's character in the process of policy making is also very significant. Media also plays an influential role in developing opinion about foreign institutions. This attribute makes them the fourth pillar of state. 
It is said that media controls the content according to their ideological preferences, constraints by their organization, and in accordance to the specifications of consumers (Neuman, Just \& Crigler, 1992, p. 120). This is a very important reason that when some information is disseminated through the media it greatly affects thought processing of consumers. During wars, mass media selects some "facts" and ignores the rest. And "omission", becomes the most important technique of information where some things are kept hidden (Rutenberg \& Carter, 2001).

History tells us numerous stories where psychological warfare is done through mainstream media (Kumar, 2006). Psychological warfare is considered a tremendously significant tool by states globally to conserve their supremacy (Whittons, 1971). The modern world is no exception. States are always engaged in efforts to instigate and influence other states, either friendly or hostile, and media war is a very important tool of it (Palmers \& Perkins, 2005).

As it is quite clear that mass media holds a very pivotal place in today's societies. Many people solely count on the information they receive through media and develop their perceptions about the world around them through the eyes of the media. The present research aims to explore the themes which The Washington Post used to portray the picture of Pakistan. It is a topic which needs direly to be explored. As Pakistan is having very negative image internationally (Ali, Jan \& Saleem, 2013). Especially for those people who don't have any first-hand information and are dependent on media (Fan \& Shahani, 2016). The current research will contribute to understand that how US media is portraying Pakistan since 9/11 that is called an ally in the war on terror by US leaders. The current research is unique because a thematic analysis of the editorial content of The Washington Post was done which provided very insightful results and opened new dimensions of research in media studies in Pakistani context.

\section{Literature Review}

A rigorous review of the previous studies was conducted to find out the results of the past researches about image framing in US media. It was observed that numerous studies have been conducted by different researchers and most of these studies concluded that US media adopts a biased stance towards Muslims and Pakistanis.

Lent (1977) said that US media does not cover every kind of global issue but only those topics are covered which have some special feature i.e., suppression policies, reporting of problematic situation, state interest, and most importantly to create certain types of images of other countries and nations. "Pictures in our heads" notion given by Lippman (1922) is quite accurate in understanding the cultivation of image of foreign countries through media. Turk (1986) studied opinion of people about other countries, that is usually develops through media that either people think of other countries as, "affluent ally" and "poor enemy". A very important reason behind such thoughts is that information regarding other states is an unobtrusive issue. Yagade \& Dozier (1990) defined and it was cited by Gonzenbach (1996, p. 8) that obtrusiveness of a topic is "that how much people have first-hand information regarding that issue". People are more dependent on media for information that they cannot access directly.

Zhang and Meadows III (2012) studied the correlation between the image of a country in US media and subsequent public opinion of that country. They concluded that a strong relation exists between the two. People thought about foreign countries in the same way as media presents them. They analyzed the content of The New York Times and concluded that the states that were given prominent coverage in the newspapers were thought to be important by the media consumers.

Boulding (1969) presented some features that play a significant role in the image building of a foreign country. Relationships and alliances, wars and combats between two nations, geographical space, robust and frail features regarding politics, monetary and armed situations are some aspects that contribute a lot in the image building of a foreign country. Ahmed (2006) described that the positive or negative 
presentation of a foreign country regarding monetary aspects, history, politics, defense, religion, diplomatic issues contributes tremendously in the image building of that country among the public.

It was observed that terrorism reporting is a genre of news presentation that has very strong impact on image building of foreign nations in US mass media (Powell, 2011, p. 102). Some previous researches concluded that US media adopts a very biased stance while reporting about Islamic countries (Khan, 2008). Usually they are presented as direly dangerous to the western communities. He further explored that Pakistan though a US ally in War on Terror, still receives coverage in US papers as of a foe. On the contrary Ali's (2008) results did not support Khan's results. Ali studied the image of Pakistan as presented by News week and Time magazine and found a more positive coverage given to Pakistan by these two news magazines. Shah's (2014) results were contrary to Ali's (2008). He investigated image of Pakistan in The Daily Telegraph and found that approximately 53\% articles framed Pakistan negatively, approximately $15 \%$ positively and the rest presented Pakistan neutrally, making the ratio of negative portrayal the highest.

Ali (2012) studied the image framing of Islamic states in US news magazines News week and Time magazine and observed that the ratio of unfavorable presentation was highest in comparison to neutral or favorable presentation. Siraj (2006) also worked on portrayal of Pakistani state in US press. He observed that relations among Pakistani and Indian governments was the most repeated topic in US media about Pakistan while terrorism remained second most covered issue after it. Zhang and Meadows III (2012) identified that when reporting about India Pakistan relations US media presents a negative picture of Pakistan. While reporting terrorist incidents it adopts an "us" versus "them" stance (Powell, 2011). As experts say that US media usually covers issues that receive negative coverage (Shoemaker, Danielian and Brendlinger, 1991). US media is considered very credible for people. It has also been verified that media users adopt the stance of the news organizations from whom they get information (Brewer, 2002). If American media usually covers issues in a negative way then in the light of the previous literature, American media consumers would have negative opinions about those issues.

It is quite clear from all the above mentioned literature that media presentation of a country has a great influence on the subsequent public opinion about that country. If Pakistan has a worldwide negative image media coverage of international media outlets definitely has something to do with it. That is why the present research was executed to understand how US elite media especially The Washington Post is treating Pakistan in its editorials. The review of the relevant literature shows that no such exhaustive study on this topic has ever been conducted before to understand US media's coverage of Pakistan through thematic analysis. So with the help of the present research, a latest dimension of research will be opened for future researches. The following research question is formulated for the study.

RQ1 How Pakistan's image was presented by The Washington Post from 2001 to 2016?

RQ2 What themes were used by The Washington Post to depict Pakistan?

\section{Method}

For this study, qualitative research design had been employed because this design was descriptive in nature and had comprehensive approach. Thematic analysis was employed for this study because it aimed to explore the stance of coverage regarding Pakistan image. It was based on grounded theory and development of cultural model which required more interpretation by the researcher. Codes were generated from the data that represented identified themes from the data. Corbin and Strauss (2008) discussed the techniques and procedures of thematic analysis in detail. Thematic analysis was widely used qualitative analytic method in the field of social sciences (Boyatzis, 1998; Roulston, 2001).

\subsection{Sample for the study}

This study selected editorials from The Washington Post that had the word "Pakistan" in the title or in 
first paragraph of the editorial published during approximately sixteen years, from First September 2001 to $31^{\text {st }}$ December 2016. The data was retrieved from Lexis-Nexis database. Total 116 editorials were analyzed from The Washington Post.

\subsection{Data analysis}

This study utilized inductive thematic analysis. After coding newspaper editorials, the themes emerged from the data. Thematic analysis is based on three types of coding namely open coding, axial coding and selective coding (Strauss \& Corbin, 1998). During the initial process, the researcher started with open coding and identifies various open codes from the data. Open codding did not explain the data but it identified different codes (Charmaz, 2006; Strauss \& Corbin, 1998). During the second step, axial coding, the researcher started to connect various codes and developed categories and subcategories. However, in the last step, selective coding, the data had to be read carefully by the researcher and the categories from data were integrated to structure theoretical framework (Strauss \& Corbin, 1998). In this case, the core categories and themes were identified. Themes were the basic idea that answered the research question of the study. The researcher utilized NVIVO 10 for coding the data.

\section{Findings}

By analyzing the editorials the following themes emerged.

\subsection{Pakistan backing Taliban}

In many of the editorials, after 9/11 attacks it was noted that The Washington post stressed that Pakistani government supported Taliban activities. It was narrated that some segments from Pakistan army are involved to train these militants. It was noted that at one side The Washington post appreciated Pakistan's efforts to curb terrorism but on the other hand, the American press showed their reservations regarding Pakistan's role in war on terror. It was observed in many editorials that American newspapers doubted the efforts of Pakistani government regarding war on terror. The newspapers wrote that Pakistan intelligence services facilitated those freedom fighters that were working in Indian occupied Kashmir. It was the interesting factor that at one side, Pakistan was framed as Non-NATO ally in the war on terror but on the other hand, the country was suspected for giving support to the terrorists.

An editorial on November 1, 2003, the newspaper wrote that the capital of Baluchistan, Quetta was a new headquarter for terrorist groups. Musharraf was condemned for his polices relating to Taliban. It was argued that local political leaders were very much supportive to the terrorist movements. Boarder security was also blamed to give support to the terrorists for free movements. It was declared that Pakistan had become heaven for the terrorists where these groups were working freely. Later on, in 2010, another terrorist incident took place in New York that was Time Square bombing. American press again started to blame Pakistan for the incident. Even, from July to August, when Pakistan was under crisis they did not give any exception to her. Overall, it was noted that Pakistan image was framed as country which was participating in war against terrorism but at the same it had connections with the terrorist groups.

\subsection{Negative image of President Musharraf}

Second theme that was dominantly observed from the data was the negative portrayal of President Musharraf. He was framed as hypocritical, cunning and undependable person by The Washington Post. For instance in an editorial on May 15, 2002, the newspaper criticized Musharraf for his referendum. During 2002, the Washington Post portrayed him in a negative stance. He was repeatedly condemned for creating disturbance in India and Kashmir and supporting militants. It was argued that President Musharraf facilitated North Korea for developing their nuclear arsenal. Pakistan was referred as "unstable and dangerous country".

The Washington Post continuously stressed that Pakistan was unreliable ally that did not provide full support in war against terrorism. However, only one editorial was noted in 2004, where President Musharraf was appreciated for his efforts to fight against the terrorists. Moreover, Musharraf's peace talks with Indian Prime Minister Mr Atal Behari Vajpai were also appreciated by the newspaper and it was 
hoped that the things between Pakistan and India would get better in future.

In another editorial the newspaper expressed distrust and prejudice regarding Musharraf's concept of enlightened moderation that was introduced in 2004. The Washington Post argued that President Musharraf could not be trusted. Overall, the editorial concluded that Musharraf was not trust worthy, he was getting huge amount of aid from America but in return he was not working properly.

\subsection{Democracy in Pakistan}

There were number of editorials noted which discussed this issue. From the perspective of democracy, President Musharraf was denounced for over throwing democratic government and not holding elections in the country. Moreover, the President's clashes with the judiciary and holding two offices were also the matter of concern for American press.

The newspaper wrote that President Musharraf should talk to political leaders in Pakistan and should start the process of fair elections in the country. The emergency which the President imposed in the country was badly criticized by the press. He decided to resign as army chief on November 28, 2007. Later on general elections were conducted in the country and Pakistan People's party came in power. However, Musharraf's successor Mr. Ishfaq Kiyani was framed in favorable stance by The Washington Post.

After elections the portrayal of Pakistan in the US press still remained negative. Musharraf was framed as self-centered leader who always saved himself at the expense of Pakistan's best interests. Mr. Yousaf Raza Gillani became the Prime Minister of Pakistan and later on Asif Ali Zardari became new President of Pakistan. But still Pakistan was framed as a country that supported terrorists.

From 2012, Pakistan politics was majorly discussed by the newspapers. But The Washington Post was not satisfied with the working of civilian governments in the context of combating terrorism. The issues of Taliban, terrorism and disorder were highlighted by the media but the stance always remained antiPakistan.

\subsection{Nuclear technology and Pakistan government}

Another theme that was observed from the data was the nuclear technology and Pakistan. The US media was much concerned about Pakistan regarding this issue. The media expressed their concerns many times that terrorists could get nuclear technology from Pakistan that could be very dangerous for all the world. From 2002 onwards Pakistan was blamed for providing nuclear technical assistance to North Korea and Iraq. The newspaper expressed its concerns that Pakistani nuclear arsenal is not in safe hands. The technology could be transferred to the terrorists. It was discussed in the US press that Pakistan's Intelligence agencies trained Taliban and provided them shelter. Later on these terrorists created chaos in India and Kashmir. During 2004 Pakistan faced the rage of The Washington Post regarding the nuclear technology scandal. General Pervaiz Musharraf and Dr. A.Q. Khan were especially condemned for providing nuclear technology to North Korea, Iran, and Libya.

\subsection{Pakistan's operation against terrorism}

Moreover, few of the editorials noted relating to Pakistan's operations against terrorists working within the country. Pakistan army started a war against the terrorists in Mangora that was the capital of Swat. Obama administration initiated measures to strengthen Afghanistan and Pakistani areas. Pakistan army in short time cleared the area and ousted the terrorists from Mangora. But The Washington Post remarked that there were certain elements in Pakistan army and intelligence which supported Taliban and collaborated with them. The US's collaboration with Pakistan was regarded as shaky partnership and it was narrated that the governments in Pakistan and Afghanistan were politically weak and could not control terrorist elements in their countries.

During 2014, Pakistan army attacked militants and in its retaliation the terrorists attacked Army Public School in Peshawar, and "wantonly slaughtered at least 132 children and nine staff members." President Obama considered it as a "heinous act". The newspaper valued the actions taken by Gen. Raheel Sharif in 
combating terrorism. It was observed that when the American press appreciated Pakistan's efforts against terrorism it was blanketed in doubts. It seemed that American newspaper intentionally wanted to write something bad for Pakistan.

\subsection{Indian terrorist attacks}

Another aspect was noted that if any terrorist activity happened in India, it was framed under anti Pakistan stance. Indian parliament attacks were portrayed as "terrorist attacks sponsored by Pakistan." It was observed if any terrorist activity occurred in India it was framed as it was supported by Pakistan. In this case, it could be said that the US newspapers toed Indian view point. It was repeated continuously that Pakistan supported terrorism and Alqeda. Moreover, the insurgency in Indian occupied Kashmir was due to Pakistan's involvement. Later on Pakistan was blamed for supporting attack on Indian embassy in Kabul, Afghanistan.

On November 26, 2008, there were terrorist attacks in Mumbai, India which killed 174 people including six Americans. Pakistan was targeted as responsible for these attacks by the Washington Post. It was argued that guerrilla organization, Lashkar-i-Taiba was "supported by Pakistani military intelligence to combat against India. In short, it was noted that Indian propaganda against Pakistan was supported by the US newspapers.

\subsection{US military operation and Osama bin Laden}

During 2011, Pakistan had problematic relationship with America. On May 02, 2011 Osama Bin Laden was killed by American forces operation in Abbottabad. The US press again accused Pakistan for giving shelter to Osama Bin Laden. As the Washington Post wrote that "with suspicions high that Osama bin Laden enjoyed some semblance of official protection, the Obama administration rightly decided to proceed without notifying Pakistan." However, by attacking Pakistan's sovereignty and conducting operation within Pakistan by American forces is regarded as "lawful." Pakistan was framed as playing "double game" with America and a country which harbored extremists. Moreover, Pakistan's weak democracy was also targeted by eh press.

From 2011 to 2015 drone attacks and terrorism remained highlighted in the media agenda of the US press. Although Pakistan army did huge efforts to combat terrorism but it was hardly acknowledged by the US newspapers. However, the bilateral relationship of Pakistan and Afghanistan was described in positive manner and stressed to strengthen this relationship. But it was doubted that Pakistan did not have uniform policy towards terrorists .

\subsection{Social issues in Pakistan}

Lastly, the social issues in Pakistan were discussed in some of the editorial of the Washington post. It was noted that very few social issues from Pakistan were raised by the Washington post. In 2002, Pakistani woman, Mukhtaran Mai was gang raped. In 2005 Lahore High Court released five out of six accused in this case. The newspaper discussed the pathetic plight of such women in Pakistan and condemned the insensitive attitude of the Pakistani government. The issues related to women plight, child labor, polio, chaos and problems related to Pakistani society got attention in American press.

Another incident that got immense attention was the case of Malala Yousafzai. A Pakistani girl from Swat who shot by Taliban for raising voice against Taliban oppression and demanding rights for women. It was one of the incident in which Pakistan was able to get favorable stance from The Washington Post. Malala Yousafzai was considered as a ray of hope for women in that area. Overall, there were limited number of editorials noted which highlighted social issues in Pakistan.

\section{Discussion and Conclusion}

The researchers formulated two research questions to gauge through the present research. The first research question was about the image presentation of Pakistan in the editorials of The Washington Post. 
The rigorous qualitative analysis showed that

Editorials of The Washington Post circulated from September 10, 2001 to December 31, 2016, were deeply analyzed and an abundance of derogatory and negative words were found. Phrases and sentences for example "Pakistani terrorist groups" (December 21, 2001, Pg. A42), "supposed freedom fighters............. supported........by the Pakistani military's own intelligence service" (December 21, 2001, Pg. A42) were found to present Pakistan. General Pervez Musharraf was harshly criticized by The Washington Post. At the time when he was the president of the country he was accused of "blatantly broken his promise" (December 1, 2002, Pg. B06). Pakistan was called "the world's single largest haven of Islamic terrorists" (June 30, 2003, Pg. A14). The results were endorsed by previous researchers (Ali, et al., 2013). They identified that American media presents a negative picture of Pakistan by presenting her as a secure refuge for terrorists.

In the words of Yousaf (2015) "The news coverage of Pakistan by the AP was decidedly negative. News related to terrorism was often framed in a way that presented Pakistan as responsible for the widespread terrorism in the region (p. 3056)." It is quite obvious that presentation of Pakistan in The Washington Post was categorically deleterious. The Washington Post used the ideology of "others" to portray Pakistan. Dijk (2001) maintains that the ideologies of journalists are reflected in opinion articles and eventually contribute in developing the discourse structure of media (p. 21). Pakistani government supported diligently the war on terror initiated by US government. Even than US media put in every effort to develop a derogatory image of Pakistan globally. As confirmed by Saleem (2007) US media usually portrays those countries in a negative way where America is somehow involved in war. A very pertinent element to consider here is that most of the negative image building is done indirectly. The Washington Post rarely accused Pakistan in a direct way. The editorialists did is so tactfully that it became unidentifiable for the common readers.

The second research question was about the themes that The Washington Post was using to depict Pakistan. Eight themes were identified by the researchers to gauge the image of Pakistan. The first theme that emerged was Pakistan's support to Taliban. Pakistan was vehemently criticized for this. She was repeatedly accused of backing up terrorists. The case of Daniel pearl was also discussed at length in this regard. Pakistani government and military personnel were also blamed for it. President Pervez Musharraf was one person who faced the most criticism. He was discussed in much abundance but always in a very retributive way. One of the main reasons of such kind of portrayal could be the compromise on democracy which he did when he assumed the office of President of Pakistan. Even after the restoration of democracy in Pakistan, she usually received the coverage as a volatile and weak country. Another theme was about the nuclear arms that government of Pakistan holds. In this regard Dr. A. Q. Khan and President Musharraf were accused of at many instances for selling nuclear arms to rouge states. It was observed that editorial writers at The Washington Post were not satisfied with the operations of Pakistani government to combat terrorism. Though the measures of Gen. Raheel Sharif were discussed in a slightly positive way but overall Pakistani government did never receive appreciation. Pakistan was also severely condemned for terrorist attacks on Indian Parliament. It was accused of having involvement in these attacks. Pakistan was accused of playing a double game in the theme of Osama Bin Laden. Drone attacks were treated as inevitable option for Pakistan. In the theme of social issues, the social structure of Pakistan was once again presented in an unfavorable way by presenting the cases of Mukhtaran Mai and Malala Yousafzai.

Van Dijk (1988) said that powerful and influential people who run different parts of organizations of discourse and communication may influence their organizations. Thus it becomes a matter of vital importance that who is regulating issues and themes. In media organizations editors at multiple levels control the content (Gans 1979; van Dijk 1988). Generally Pakistan was discussed in a very negative way by the editorialists of The Washington Post through the themes which sketched Pakistan in a heinous way. It has also been established through research that if a country is given unfavorable coverage in American press, readers start thinking about her in a negative light (Wanta, Golan and Lee, 2004). In the light of the 
above mentioned discussion it was concluded that in developing a negative image of Pakistan globally The Washington Post remained a very influential contributor. Pakistan must adopt some viable strategy to overcome this problem.

\section{References}

Ahmad, H. (2006). A comparative study of the coverage of Pakistan in New York Times and Dawn. Pakistan Journal of American Studies, 24(1/2), 37.

Ali, S. (2008). US mass media and images of Pakistan: Portrayal of Pakistan in News Week and Time magazines (1991-2001). American Communication Journal, 10(2). http://www.acjournal.org/journal/2008/Summer/6USMassMediaandimageofPakistan.pdf

Ali, S. (2012). American Print Media \& Muslim World: Portrayal of the US Allies, Enemies and Neutral Muslim Countries in "Newsweek" and "Time" Magazines. A Framing Perspective. Pakistan Journal of Islamic Research, 9(9), 41-69.

Ali, Z., Jan, M., \& Saleem, N. (2013). Portrayal of Pakistan by US leading news magazines. Science International, 25(4). 965-970.

Boaz, C. (2005). War and foreign policy framing in international media. Peace Review: A Journal of Social Justice, 17(4), 349-356.

Boulding, K.E. (1969). National image and international system. In James N. R. (Ed.). International Politics and foreign policy (pp. 422-431). London: Collier Macmillan Inc.

Boyatzis, R.E. (1998). Transforming Qualitative Information: Thematic Analysis and Code Development. London: Sage Publications.

Brewer, P. R. (2002). Framing, value words, and citizens' exolainations of their issue opinion. Political Communication, 19, 303-316.

Carter, B., \& Rutenberg, J. (2016). After the attacks: Television; viewers again return to traditional networks. New York Times Web site. Available at http://www. nytimes. com/2001/09/15/us/aftertheattacks-television-viewers-again-return-to-traditional-networks. html . Accessed May, 30.

Charmaz, K. (2006). Constructing grounded theory. A practical guide through qualitative analysis. Thousand Oaks, CA:Sage Publications.

Corbin, J., \& Strauss, A. (2008). Basics of qualitative research: Techniques and procedures for developing grounded theory. Thousand Oaks, CA: Sage.

Cresswell, J.W. (1994). Research design: qualitative and quantitative approaches. Thousand Oaks, CA: Sage.

Denzin, N. (1994). The Art and Politics of Interpretation. In N. Denzin \& Y. Lincoln (eds.), Handbook of Qualitative Research (pp. 500-15). London: Sage.

Fan, Y., \& Shahani, A. (2016). Country image of Pakistan: a preliminary study. International Journal of Tourism Research, 18(3), 220-227.

Gonzenbach, W. J. (1996). The Media, The President and The Public Opinion, A Longitudinal Analysis of the Drug Issue, 1984-1991. Mahwah, NJ: Lawrence Erlbaum Associates, Publishers.

Khan, A. (2008). The Image of Pakistan in Prestigious American Newspaper Editorials: A Test of the Media Conformity Theory. Strategic Studies, (XXVIII) $2 \& 3$.

Kumar, D. (2006). Media, War and Propaganda: Strategies of Information Management During the 2003 Iraq War. Communication and Critical/ Cultural Studies, 3: 1, 48-69. DOI: $10.1080 / 14791420500505650$

Lent, J. A. (1977). Foreign News in American Media. Journal of Communication, 27(1), 46-51, DOI: 
10.1111/j.1460-2466.1977.tb01796.x

Lippmann, W. (1922). Public Opinion. New York: Harcourt, Brace \& Company.

Neuman, R. W., Just, M. R. \& Crigler, A. N. (1992). Common Knowledge. News and the construction of political meaning. Chicago: University of Chicago Press.

Palmers, N. D. \& Perkins, H. C. (2005), International Relations, A World Community in Transition (3rd Edition). New Delhi: A.I.T.B.S. Publishers.

Powell, K. A. (2011). Framing Islam: An Analysis of US Media Coverage of Terrorism Since 9/11. Communication Studies, 62(1), 90-112, DOI: 10.1080/10510974.2011.533599

Roulston, K. (2001). Data analysis and 'theorizing as ideology'. Qualitative Research, $1(3), 279-302$.

Saleem, N. (2007). US media framing of foreign countries image: An analytical perspective. Canadian Journal of Media Studies, 2(1), 130-162. http://citeseerx.ist.psu.edu/viewdoc/download?doi=10.1.1.453.581\&rep=rep1\&type=pdf

Shah, M. A. (2014). Depiction of Pakistan by English newspaper: The Daily Telegraph. The International Asian Research Journal, 2(3): 34-41.

Shoemaker, P. J., Danielian, L. H., \& Brendlinger, N. (1992). Deviant acts, risky business, and U.S. involvement: The newsworthiness of world events. Journalism Quarterly, 68: 781-795.

Siraj, S. (2006). Image of Pakistan in the US Media. University of Southern Illinois. Unpublished PostDoctoral research

Turk, S. (1986). Images of foreign nations: a descriptive and functional analysis (Doctoral dissertation, University of Washington).

Uudelepp, A. (2008). Propaganda instruments in political television advertisements and modern television commercials. (Abstract). Unpublished PhD thesis, University of Tallinn.

Whitton, J. B. (1971). Hostile international propaganda and international law. The Annals of the American Academy of Political and Social Science, 398(1), 14-25.

Zhang, C. \& Meadows III, C. W. (2012). International Coverage, Foreign Policy, and National Image: Exploring the Complexities of Media Coverage, Public Opinion, and Presidential Agenda. International Journal of Communication 6, 76-95. 
